\title{
PEMANFAATAN POTENSI DESA DALAM PENGEMBANGAN DESA WISATA DI DESA PULAU LEGUNDI KECAMATAN PUNDUH PEDADA KABUPATEN PESAWARAN
}

\author{
Asmaria $^{1}$, M.Fikri Akbar ${ }^{2}$, Kuswarak ${ }^{3}$ \\ Universitas Sang Bumi Ruwa Jurai, Administrasi Negara, Fisipol \\ Email:asmariafisip@gmail.com; fikri.m.akbar@gmail.com; kuswarak23@gmail.com
}

\begin{abstract}
Abstrak
Kegiatan pengabdian kepada masyarakat ini berupa penyuluhan yang berjudul "Pemanfaatan Potensi Desa dalam mengembangkan Desa Wisata di desa Pulau Legundi Kecamatan Punduh Pedada Kabupaten Pesawaran. Desa Pulau Legundi merupakan desa yang terletak di sebuah kepulau yang sangat berpotensi untuk dikembangkan sebagai desa wisata, dimana kondisi alamnya yang berupa pantai, pulau dan laut sangat cocok sekali di bentuk sebagai desa wisata bahari. Namun saat ini potensi alam yang ada belum tergali dan belum dimanfaatkan secara maksimal untuk menjadi obyek wisata lebih lanjut dapat dibentuk desa wisata. Khalayak Sasaran pengabdian ini sebanyak 30 orang terdiri dari tokoh masyarakat, karang taruna dan petugas pemerintahan desa. Pengabdian Kepada Masyarakat kali ini menggunakan metode Penyuluhan yaitu dalam bentuk ceramah. Manfaat kegiatan pengabdian ini adalah untuk menambah pengetahuan dan wawasan masyarakat untuk dapat menggali dan memanfaatkan potensi desa yang ada guna pengembangan desa wisata dan meningkatkan perekonomian masyarakat. Pelaksanaan pengabdian kepada masyarakat ini ditanggapi dengan baik oleh peserta hal ini ditandai dengan banyaknya pertanyaan yang dilontarkan selama penyuluhan berlangsung, materi yang disampaikan sangat bermanfaat bagi peserta, terkait banyak potensi alam indah yang mempunyai nilai ekonomi bila dimanfaatkan sebagai desa wisata. Dan mengusulkan kembali untuk mengadakan kegiatan seperti ini dengan materi yang lebih kearah teknis pembentukan Desa Wisata dan memohon dijelaskan cara memperoleh kucuran dana untuk mengolah potensi tersebut sehingga memiliki nilai jual di lakoasi desa wisata
\end{abstract}

Kata kunci: Potensi desa, desa wisata.

\begin{abstract}
This community service activity is in the form of counseling entitled "Utilization of Village Potential in developing a Tourism Village in the village of Pulau Legundi, Punduh Pedada District, Pesawaran Regency. The village of Pulau Legundi is a village located on an island that has the potential to be developed as a tourist village, where its natural conditions in the form of beaches, islands and the sea are very suitable to be formed as a marine tourism village. However, currently the existing natural potential has not been explored and has not been maximally utilized to become a tourist attraction. Further tourism villages can be formed. The target audience of this service is 30 people consisting of community leaders, youth organizations and village government officials. This time, Community Service uses the extension method, namely in the form of lectures. The benefit of this service activity is to increase the knowledge and insight of the community so that they can explore and take advantage of the potential of the existing village to develop tourist villages and improve the community's economy. The participants responded well to this community service. This was indicated by the many questions asked during the counseling, the material presented was very useful for participants, related to the many potentials of beautiful nature that have economic value if used as a tourism village. And proposing to re-organize activities like this with materials that are more technical towards the formation of a Tourism Village and ask for an explanation of how to get the disbursement of funds to process this potential so that it has a selling value in the tourism village lakoasi
\end{abstract}

Key words: Village potential, tourism village. 
Seminar Nasional Penelitian dan Pengabdian kepada Masyarakat Universitas Sang Bumi Ruwa Jurai Tahun 2020

\section{PENDAHULUAN}

Indonesia merupakan negara yang mempunyai banyak ragam potensi alam. Potensipotensi tersebut tentu dapat dikembangkan supaya membawa dampak positif bagi industri pariwisata di Indonesia, Indonesia memang terkenal dengan potensi pariwisatanya yang beraneka macam. Mulai dari pantainya yang indah, pegunungan yang hijau, dan peninggalan-peninggalan bersejarah seperti candi juga banyak ditemukan di Indonesia, sehingga tidah aneh apa bila Indonesia di katakana "Zambrut di Katulistiwa" yang merupakan daya tarik pariwisata yang tidak dapat ditemukan di negara lain, sehingga banyak wisatawan domestik maupun luar negeri yang ingin menikmati keindahan alam tersebut

Provinsi Lampung merupakan salah satu provinsi di Indonesia yang kaya akan sumberdaya kelautan dan pesisir baik keindahan wilayah pantai pesisirnya maupun sumber daya dalam bentuk produksi hasil perikanan dan kelautannya. Pariwisata bahari dikembangkan agar mampu mendorong kegiatan ekonomi dan meningkatkan citra provinsi Lampung bahkan Indonesia, untuk meningkatkan kesejahteraan masyarakat lokal, serta memberikan perluasan kesempatan kerja dengan model pengambangan ekowisata. Istilah "ekowisata" dapat diartikan sebagai perjalanan oleh seorang turis ke daerah terpencil dengan tujuan menikmati dan mempelajari mengenai alam, sejarah dan budaya di suatu daerah, di mana pola wisatanya membantu ekonomi masyarakat lokal dan mendukung pelestarian alam.

Pengembangan desa wisata merupakan salah satu upaya yang bisa ditempuh untuk memberdayakan masyarakat serta memacu untuk mengembangkan potensi desa yang mengarah pada peningkatan produktivitas masyarakat agar lebih mandiri. Bupati Pesawaran sangat urgen terhadap pengembangan wisata di wilayah yang dipimpinnya yaitu Kabupaten Pesawaran, dimana setiap desa yang berada di wilayah Kabupaten Pesawaran di tekankan untuk mengembangan pariwisata pengan memanfaatkan potensi yang ada. Hal mendasar yang dilaksanakan oleh Pemerintah Kabupaten Pesawaran dalam mewujudkan Bumi Wisata yaitu dengan penyediaan infrastruktur dasar berupa pembangunan jalan sebagai akses dalam mengembangkan potensi pariwisata di Kabupaten Pesawaran, menjamin rasa aman dan nyaman kepada wisatawan, serta memberdayakan masyarakat lokal untuk mengurangi angka kemiskinan dan pengangguran.

Pengembangan desa wisata ini harus memperhatikan kemampuan dan tingkat penerimaan masyarakat setempat yang akan dikembangkan menjadi desa wisata tersebut. Hal ini dimaksudkan untuk mengetahui karakter dan kemampuan masyarakat yang dapat dimanfaatkan dalam pengembangan desa wisata, menentukan jenis dan tingkat pemberdayaan masyarakat secara tepat. Untuk mengetahui penerimaan masyarakat terhadap kegiatan pengembangan desa wisata; 1) Tidak bertentangan dengan adat istiadat budaya masyarakat setempat; 2) Pengembangan fisik yang diajukan untuk meningkatkan kualitas lingkungan desa; 3) Memperhatikan unsur kelokalan dan keaslian; 4) Memberdayakan masyarakat desa; 5) Memperhatikan daya dukung dan daya tampung serta berwawasan lingkungan.2Tentunya perkembangan industri pariwisata yang dalam hal ini adalah desa wisata mempunyai dampak bagi ekonomi suatu wilayah, antara lain pemerataan kesempatan kerja, peningkatan pendapatan masyarakat, serta peningkatan pendapatan daerah.

Sebagai salah satu desa yang berpotensi dijadikan desa wisata di Kabupaten Pesawaran adalah desa Pulau Legundi, Desa Pulau Legundi tentu saja akan dapat memberikan kontribusi yang tidak sedikit bagi masyarakat setempat bila potensi yang ada di jadikan Objek wisata yang menawarkan pesona alam bahari berupa pantai dengan pasir yang putih, bermain di laut yang jernih, memancing ikan dan lain sebagainya 


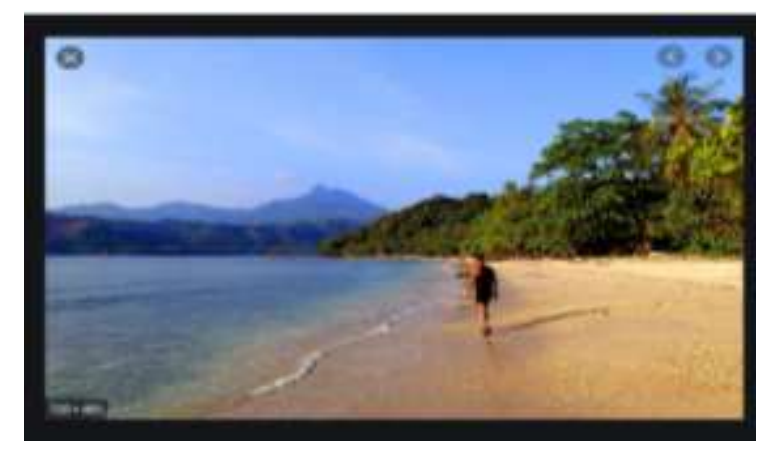

Gambar 1. Pantai yang indah di Pulau legundi

Legundi adalah desa dan pulau di kecamatan Punduh Pedada, Kabupaten Pesawaran, Lampung, desa Pulau Legundi terletak di lepas Selat Legundi. Desa Pulau Legundi memiliki luas tanah mencapai $2500 \mathrm{Ha}$, dengan luas perkebunan kurang lebih $1000 \mathrm{Ha}$ dan luas tanah kering dan basah sekitar 1000 Ha dan sisa nya daerah pemukiman. Jumlah penduduk di desa legundi sebanyak 1978 jiwa dengan jumlah kepala keluarga 520 KK dengan rincian laki-laki 973 jiwa dan perempuan 1005 jiwa.

Potensi sumber daya alam Desa Pulau Legundi menjadi salah satu obyek wisata unggulan di Pesawaran dan dapat menjadi satu kebanggaan bagi masyarakat apabila keindahan alam tersebut sudah dikenal masyarakat luas. Desa Legundi banyak sekali memiliki objek pariwisata seperti batu kurung kambing, pulau kairong, legundi tuha, pulau petapaan,pulau sejebi, pulau serdang, pulau seserot, pulau siuncal dan pulau umang-umang.

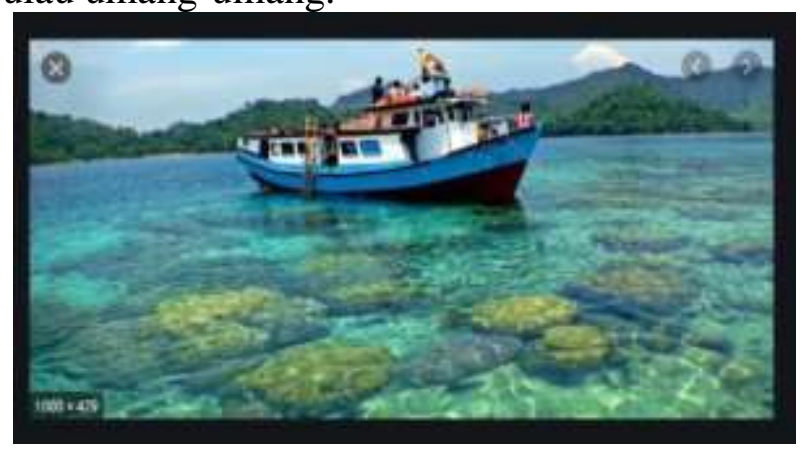

Gambar 2. Air laut yang jernih

Pariwisata seringkali dipandang sebagai sektor yang sangat terkemuka dalam ekonomi dunia. Kalau sektor tersebut berkembang atau mundur maka banyak negara akan terpengaruh secara ekonomis, karena Kegiatan pariwisata hakikatnya merupakan kegiatan yang sifatnya sementara, dilakukan secara suka rela dan tanpa paksaan untuk menikmati objek dan atraksi wisata. Dalam perkembangannya industri pariwisata ini mampu berperan sebagai salah satu sumber pendapatan negara. 


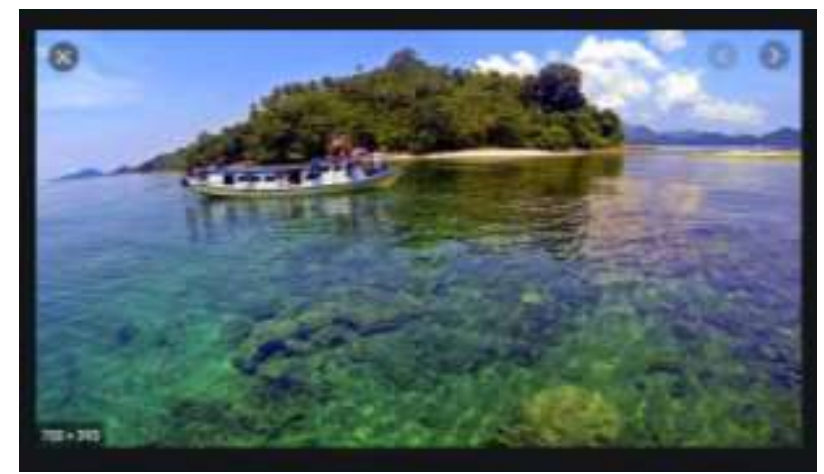

Gambar 3. Pemandangan bawah laut

Pengembangan desa wisata merupakan salah satu upaya yang bisa ditempuh untuk memberdayakan masyarakat serta memacu untuk mengembangkan potensi desa yang mengarah pada peningkatan produktivitas masyarakat agar lebih mandiri.

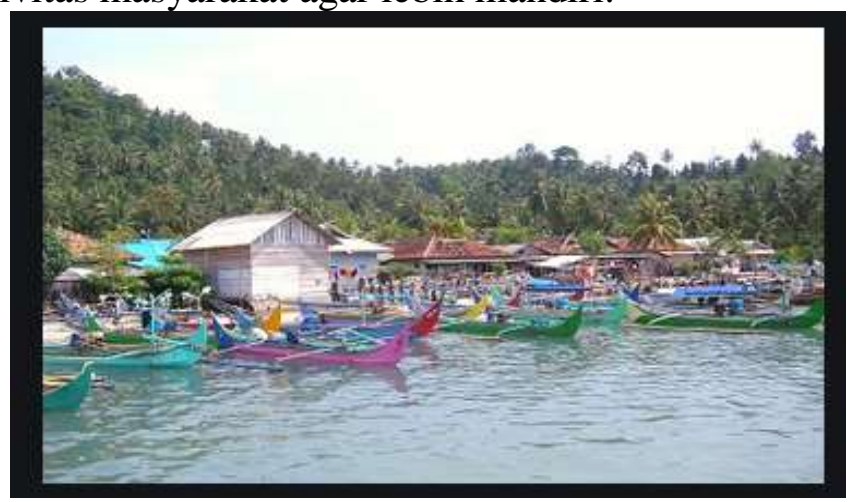

Gambar 4. Tersedianya Transportasi

Dalam situasi perekonomian yang serba sulit seperti sekarang ini dengan tingkat kesempatan kerja yang menurun serta adanya kecenderungan bertambahnya angka kemiskinan dan pengangguran, sangat diperlukan suatu tindakan nyata untuk mengatasi masalah-masalah tersebut. Salah satunya adalah dengan program pemberdayaan masyarakat. Program ini dilakukan untuk menciptakan masyarakat yang lebih sejahtera, maju, dan mandiri. Usaha pemberdayaan masyarakat bisa dilakukan melalui berbagai sektor, salah satunya adalah sektor pariwisata. Apabila dikembangkan secara terpadu, sektor pariwisata dapat mendorong tumbuhnya sektor-sektor ekonomi lainnya. Perkembangan pariwisata yang berbasis pada kemampuan masyarakat setempat merupakan bentuk pemberdayaan masyarakat. Salah satu model pemberdayaan ekonomi kerakyatan dalam bidang pariwisata adalah melalui pengembangan desa wisata.

Kegiatan ini bertujuan untuk memberikan pemahaman mengenai usaha untuk mengembangkan sektor pariwisata dengan memanfaatkan potensi-potensi desa yang memang tersedia, guna mengembangkan desa wisata di desa Pulau Legundi Kecamatan Punduh Pedada Kabupaten Pesawaran

Berdasarkan potensi wilayah yang ada ada beberapa hal yang perlu dipertanyakan kembali dalam kaitannya dengan pengembangan Desa Legundi Kecamatan Punduh Pedada Kabupaten Pesawaran sebagai desa wisata, yaitu: 1) Mengapa potensi alam yang tersedia belum dikembangakan sebagai lokasi wisata? 2) Mengapa lokasi-lokasi wisata yang berpotesi masih belum memiliki nilai ekonomis 3) Mengapa masyarakat belum berperan secara aktif mengembangkan desa wisata? 4) Mengapa potensi wisata yang ada belum dioptimalkan? 
Berdasarkan perumusan masalah diatas maka ditetapkan program: Penyuluhan Pemanfaatan Potensi desa dalam Pengembangan Desa wisata

Tujuan dilakukannya Penyuluhan Pemanfaatan potensi desa dalam pengembangan desa wisata adalah: 1) Memberikan pemahaman pada masyarakat akan arti pentingnya pengembangan desa wisata yang baik. 2) Memberikan pemahaman dan wawasan mengembangkan potensi desa yang mengarah pada peningkatan produktivitas masyarakat agar lebih mandiri. 3) Memberikan pengetahuan cara menggali potensi-potensi yang dapat dikembangkan sebagai lokasi wisata 4) Memberikan ketrampilan dalam mepromosikan desa wisata.

Manfaat dilakukannya Penyuluhan Pemanfaatan potensi desa dalam pengembangan desa wisata adalah: 1) Menambah wawasan masyarakat dalam menggali potensi-potensi desa 2) Meningkatkan wawaran masyarakat tentang desa wisata

Target dan luaran yang ingin diperoleh dari kegiatan pengabdian ini adalah: 1) Masyarakat mampu menggali potensi-potensi desa yang dapat di angkat dan mempunyai nilai jual, guna meningkatkan perekonomian masyarakat, 2) Jurnal pengabdian

\section{METODE PENELITIAN}

Pengabdian Pada Masyarakat di Desa Pulau Legundi tentang Pemanfaatan Potensi desa dalam pengembangan Desa Wisata merupakan pemecahan masalah dimana potensi-potensi yang ada di desa Pulau Legundi Masih banayak yang belum terangkat dan dijadikan potensi desa wisata, kondisi alam yang indah yang menarik untuk dijadikan desa wisata. Kesadaran masyarakat masih belum tergugah untuk memanfaatkan potensi yang ada, maka perlu adanya penyuluhan tentang pemanfaatan potensi-potensi desa sehingga mempunyai nilai jual yang dapat menarik wisata untuk datang ke Desa Pulau Legundi

Yang menjadi Khalayak Sasaran dalam Pengabdian Pada Masyarakat di Desa Pulau Legundi tentang Pemanfaatan Potensi desa dalam pengembangan Desa Wisata, yaitu sebanyak 30 Orang terdiri dari: Petugas Pemerintahan desa Pulau Legundi, Tokoh masyarakat/Masyarakat desa Pulau Legundi yang terlibat secara langsung dalam kegiatan desa wisata dan Karang Taruna Desa Pulau Legundi, karena Desa Pulau Legundi merupakan sebuah pulau yang sangat indah secara alami, maka potensi ini yang perlu digali dan dikembangkan sehingga dapat menarik pendatang untuk berwisata, untuk meningkatkan kesadaran masyarakat akan arti pentingnya potesi wisata yang ada maka metode yang tepat adalah Penyuluhan dengan menggunakan teknik ceramah dan Tanya jawab (diskusi)

Adapun prosedur Pengabdian masyarakat ini adalah pertama-tama melakukan observasi ke desa Pulau Legundi untuk melihat permasalahan guna membuat analisis situasi, lalu membuat surat izin, dan tahap berikutnya adalah sosialisasi dan pelaksanaan penyuluhan. Dan tahap terakhir adalah evaluasi guna mengetahui keberhasilan pelaksanaan pengabdian masyarakat ini dan menarik kesimpulan saran dalam kegiatan ini.

Pengabdian Pada Masyarakat di Desa Pulau Legundi ini adalah melakukan penyuluhan Pemanfaatan Potensi desa dalam pengembangan Desa Wisata. Kegiatan akan dilakukan dalam kurun waktu 2 bulan, yang meliputi kegiatan observasi, pengumpulan data, publikasi dan informasi kepada para peserta, admnistrasi, pelaksanaan kegiatan dan evaluasi kegiatan.

\section{HASIL DAN PEMBAHASAN}

Kegiatan Pengabdian Kepada Masyarakat tentang Pemanfaatan Potensi Desa Dalam Pengembangan Desa Wisata Di Desa Pulau Legundi Kecamatan Punduh Pidada Kabupaten 
Pesawaran dilaksanakan pada tanggal September 2020. Kegiatan Pengabdian pada masyarakat ini berjalan dengan lancar dihadiri oleh 29 peserta dari 31 undangan. Peserta terlihat antusias dengan materi penyuluhan yang diberikan. Hal ini terlihat dari awal hingga akhir acara, semua peserta mengikuti dengan baik. Materi mengenai konsep potensi desa yang dapat dikembangan sebagai asset pariwisata, dan pengembangan peluang ekonomi yang dapat dikembangan di desa wisata. Berdasarkan hasil kegiatan dapat diidentifikasi mengenai tingkat pemahaman peserta penyuluhan adalah bahwa $75 \%$ peserta memahami konsep konsep potensi desa yang dapat dikembangan sebagai asset pariwisata, dan pengembangan peluang ekonomi yang dapat dikembangan di desa wisata.

Potensi desa Pulau Legundi yang begitu banyak bila dijadikan lokasi wisata, sedangkan masyarakat Desa Pulau Legundi lebih banyak yang memilih menjadi petani perkebunan ketimbang pengelolaan desa wisata sedangkan potensi wisata sangat tersedia, karena wilayahnya adalah kepulauan yang sangat indah secara alami, seperti pantai dengan pasir putihnya, air lautnya yang tenang, sangat cocok sekali untuk wisata dan mempunyai nilai jual yang masih belum pernah diusahakan disamping petanian.

Penyuluhan tentang Pemanfaatan Potensi Desa Dalam Pengembangan Desa Wisata Di Desa pulau Legundi Kecamatan Punduh Pidada Kabupaten Pesawaran memang nyata-nyata dibutuhkan bagi masyarakat, kebanyakan peserta mengeluhkan kurangnya pengetahuan dan pemahaman akan pemanfaatan potensi yang ada di Desa Pulau Legundi yang dapat dikembangkan menjadi asset desa wisata. Dan baru menyadari bahwa potensi desa wisata yang ada dapat dikembangkan dan dapat menjadi sumber-sumber perekonomian desa ini berarti akan dapat meningkatkan pendapatan masyarakat. Oleh karena itu masyarakat merasakan banyak manfaat yang diperoleh dari penyuluhan ini untuk memanfaatkan potensi-potensi desa dan mendorong masyarakat secara aktif dalam membangunm guna mengembangkan Desa Wisata dan menyadari bahwa Pengembangan sektor pariwisata perlu dilakukan secara terus menerus di Desa Pulau Legundi agar masyarakat dapat secara aktif dalam membangunan desa wisata untuk mencapai tujuan kesejahteraan yang diinginkan.

Pembangan sektor pariwisata ini merupakan suatu kegiatan yang menggali dan menanfaatkan segala potensi pariwisata yang ada, baik sumber daya alam dan sumber daya manusianya. Kedua potensi tersebut apabila digabungkan dan dikelola dengan baik akan memberikan manfaat bagi keduanya. Atau dengan kata lain kegiatan pariwisata adalah mengembangkan potensi desa yang kegiatan harus melibatkan masyarakat. Saat ini usaha yang dapat dijual bagi masyarakat yang sedang berkembang adalah industri pariwisata, Jadi bisa dikatakan bahwa melalui pariwisata masyarakat bisa melakukan perubahan, yang semula masyarakat terpinggirkan, kurang diberdayakan diharapkan setelah adanya pengembangan pariwisata masyarakat dapat terlibat dalam pengelolaan dan kegiatan desa wisata. Mengingat pariwisata akan menimbulkan efek kegiatan yang sangat luas, meliputi kegiatan ekonomi seperti usaha perhotelan dan sejenisnya, agen perjalanan, transportasi, restoran, toko cinderamata, berbagai usaha kerajinan, kesenian dan usaha-usaha lainnya. Itulah sebabnya pariwisata dipandang sebagai suatu industri karena didalamnya terlibat berbagai bentuk kegiatan ekonomi dan berbagai jenis tenaga kerja dan modal dengan sebagian besar menawarkan berbagai bentuk jasa Tentu hal ini akan menciptakan suatu masyarakat yang lebih maju dan mandiri.

Kegiatan pelatihan ini dapat berjalan dengan lancar. Hal ini disebabkan adanya faktor yang mendukung berjalannya kegiatan pengabdian. Hal-hal yang mendukung berjalannya kegiatan pengabdian ini dapat diidentifikasi diantaranya antusisme para peserta penyuluhan. Faktor yang mendukung kegiatan adalah antusiasme peserta untuk memahami konsep potensi desa yang dapat 
dikembangan sebagai asset pariwisata, dan pengembangan peluang ekonomi yang dapat dikembangan di desa wisata.

Antusisme dibuktikan dengan banyaknya pertanyaan yang muncul ketika pelaksanaan diskusi kelompok, serta tidak adanya peserta yang membolos selama pelaksanaan penyuluhan Lancarnya pelaksanaan kegiatan pengabdian bukan berari tanpa hambatan. Selama pengabdian ada beberapa hal yang diidentifikasi sebagai factor penghambat kegiatan pengabdian diantaranya lokasi yang jauh dan sulit di jangkau, menuju lokasi memerlukan waktu 3 (tiga) jam menyeberangi laut dari pelabuhan Ketapang. Sebagian besar mata pencarian masyarakat adalah pertanian perkebunan dan beberapa peserta kurang tertarik dengan pariwisata. Untuk mengembangkan pariwisata memerlukan modal yang tidak sedikit, walau potensi alam tersedia sangat indah.

\section{KESIMPULAN}

Kegiatan Pengabdian kepada masyarakat yang berbentuk penyuluhan Pemanfaatan Potensi Desa dalam pengembangan Desa Wisata di desa Pulau Legundi dapat berjalan dengan lancar. Hampir semua peserta antusias dan merasakan manfaat penyuluhan. Pelaksanaan pengabdian untuk masyarakat Desa Pulau Legundi dapat disimpulkan berhasil dan berjalan dengan baik. Keberhasilan ini ditunjukkan antara lain oleh :

1. Adanya kesesuaian materi dengan kebutuhan pengetahuan masyarakat untuk memanfaatkan potensi desa dalam pengembangan desa wisata

2. Adanya respon yang positif dari peserta mengingat kegiatan pengabdian merupakan kebutuhan masyarakat dalam rangka peningkatan pendapatan masyarakat

3. Sebagian besar (75\%) peserta telah memahami konsep potensi desa yang dapat dikembangan sebagai asset pariwisata, dan pengembangan peluang ekonomi yang dapat dikembangan di desa wisata.

\section{Saran}

Dari tanggapan dan pertanyaan peserta pengabdian, dalam hal ini peserta penyuluhan tentang pemanfaatan potensi desa dalam mengembaangkan desa wisata di Desa Pulau Legundi maka saran yang dapat diberikan adalah:

1. agar masyarakat Desa Pulau Legundi dapat memanfaatkan potensi potensi yang ada sehingga dapat mempercepat mewujudkan Desa Wisata

2. Agar masyarakat dapat mengembangkan kreativitasnya dalam mengembangkan perekonomian yang berkaitan dalam pengembangan desa wisata.

3. Perlu Pemasukan Modal dalam pembangunan lokasi-lokasi wisata di Desa Pulau Legundi

\section{UCAPAN TERIMAKASIH}

Terima kasih setinggi-tingginya kepada:

1. Lembaga Penelitian dan Pengambian Kepada Masyarakt Universitas Sang Bumi Ruwa jurai Yang telah me,mfasilitasi dan memberi bantuan dana sehingga kegiatan ini dapat terselesaikan dengan baik

2. Kepala Desa Pulau Legundi dan Masyarakt yang telah mempasilitasi dan berpartisipasi aktif sehingga kegiatan ini dapat berjalan den gan lancer dan baik

\section{DAFTAR PUSTAKA}


Seminar Nasional Penelitian dan Pengabdian kepada Masyarakat

Universitas Sang Bumi Ruwa Jurai Tahun 2020

Besra, Eri. (2012). "Potensi Wisata Kuliner Dalam Mendukung Pariwisata Di Kota Padang" .Jurnal Riset Akuntansi dan Bisnis Vol.12 No.1

Karyono, A. Hari. (1977) “Keperiwisataan”. Grasindo: Jakarta

Marpaung, Happy. (2000). Pengetahuan Kepariwisataan. Alfabeta. Bandung

Mariska, Ursulla Maduma Silaban. Saptono Nugroho. (2018). “Kontribusi Desa Wisata Sendang Duwur Kabupaten Lamongan Terhadap Ekonomi Masyarakat Lokal" .Jurnal Destinasi Pariwisata Vol. 6 No.2

Mubyarto, dkk. (1996). Membahas Pembangunan Desa. Aditya Media, Yogyakarta

M.Arief Anwar dkk. (2018). "Strategi pengembangan wisata berbasis kearifan lokal di Kalimantan Selatan” Jurnal Kebijakan Pembangunan Volume 13 Nomor: 2

Sajogyo, dkk.(2002). Sosiologi Pedesaan Kumpulan Bacaan Jilid II. University Press:Yogyakarta

Soekadijo, R.G. Anatomi Pariwisata (Memahami Pariwisata Sebagai "Systemic Linkage”). Jakarta: PT Gramedia Pustaka Utama..

Soetomo. (2006). Strategi-Strategi Pembangunan Masyarakat. Pustaka Pelajar. Yogyakarta

Spillane, James J.(1994).Pariwisata Indonesia. Kanisius. Yogyakarta:.

Zakaria, Faris. Rima Dewi Suprihardjo.(2014). "Konsep Pengembangan Kawasan Desa Wisata di Desa Bandungan Kecamatan Pakong Kabupaten Pamekasan”. Jurnal Teknik POMITS Vol. 3 No. 2

https://www.bumdestirtamandiri.co.id diakses pada tanggal 29 Januari 2018. 